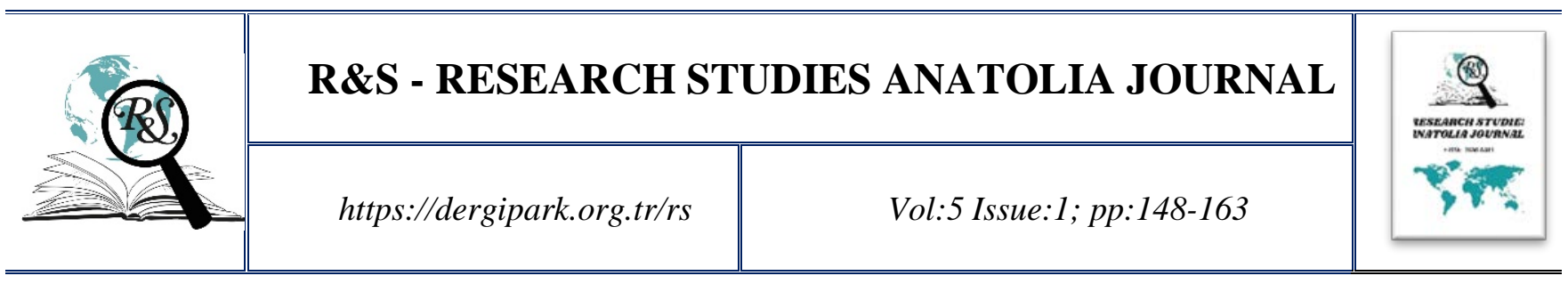

\title{
STATISTICAL EVALUATION OF EXCHANGE PERFORMANCE OF BANKS TRADED IN THE SUSTAINABILITY INDEX*
}

Sürdürülebilirlik Endeksinde Işslem Gören Bankaların Borsa Performanslarının İstatistiksel Değerlendirilmesi

\section{Ayşegül Berrak KÖTEN}

Lecturer, Dr., Istanbul Kultur University, Banking and Insurance, a.koten@iku.edu.tr Istanbul/TURKEY

https://orcid.org/0000-0002-5680-9920

Doi: $\underline{\text { https://doi.org/10.33723/rs.1051449 }}$

Köten, A. B. (2022). "Statistical evaluation of exchange performance of banks traded in the sustainability index”, R\&S -Research Studies Anatolia Journal, 5(1). 148-163.

Makale Türü: Araştırma Makalesi

Geliş Tarihi/ Arrived Date: 30.12.2021

Kabul Tarihi / Accepted Date: 25.01.2022

Yayınlanma Tarihi / Published Date: 31.01.2022

\footnotetext{
* This study was presented as a research paper at ISBES - International Sustainable Business and Economic
} Strategies Congress held on 10-11 December 2021. 


\title{
ÖZ
}

Global rekabet ortamında varlığını devam ettirmekte olan günümüz işletmelerinin ayakta kalabilmelerinde, tek başına finansal değerlerinin iyi olması yeterli gelmemektedir. İşletmelerin faaliyetlerine devam edebilmeleri adına sürdürülebilirlik ifadesi ön plana çıkmış ve buna bağlı olarak da sosyal, ekonomik ve çevresel yükümlülüklerden kaynaklı kurumsal sürdürülebilirlik kavramı ortaya çıkmıştır. Şirketlerin ekonomik, çevresel ve sosyal konularla ilgili sürdürülebilirlik stratejileri uygulamaları ve yatırımcıların bilgilendirilmesi amacıyla Borsa İstanbul çatısı altında Sürdürülebilirlik Endeksi hesaplanmaktadır. Gerçekleştirilen çalışmanın amacı, BIST Sürdürülebilirlik Endeksi çerçevesinde işlem görme hakkına sahip olan altı bankanın, endekse dahil olmadıkları dönem 2013 yılı ve dahil oldukları 2020 dönemi için borsa performans göstergelerinin anlamlı farklılık gösterip göstermediği Paired t testi yardımıyla araştırılmıştır. $\mathrm{Bu}$ amaç doğrultusunda yapılan analiz sonucunda, hisse fiyatı haricinde fiyat/kazanç oranı, piyasa değeri/defter değeri, işlem hacmi ve nakit akış oranı değişkenleri için anlamlı farklılık elde edilmiştir. Dikkat çekici nokta, endekse dahil olduktan sonra bankalar için sadece işlem hacminin artış göstermesidir. Borsa İstanbul Sürdürülebilirlik Endeksi yeni bir endeks sayılır ve endeks derinleştikçe bankaların hisse senedi değerlerinde ve diğer performans göstergelerinde yarattığı etkinin zaman içinde olumlu duruma dönüşeceği düşünülmektedir.

Anahtar Kelimeler: Sürdürülebilirlik Endeksi, Bankalar, Borsa Performansı, İstatistik Analiz.

\begin{abstract}
Good financial values are not sufficient alone for the survival of today's businesses, which sustain their existence in the global competitive environment. For businesses to continue their activities, the expression of sustainability has come to the forefront, and therefore, the concept of corporate sustainability emerged from social, economic, and environmental obligations. The Sustainability Index is calculated under the umbrella of Borsa Istanbul to ensure that businesses
\end{abstract}


implement their sustainability strategies on economic, environmental, and social issues and inform investors. The purpose of the study was to investigate whether the stock market performance indicators of the six banks which have the right to be traded in the framework of the BIST Sustainability Index for 2013, when they were not included in the index, and for 2020, when they were included, by using the Paired t-test. As a result of the analyses made for this purpose, significant differences were detected for the price/earnings ratio, market value/book value, transaction volume, and cash flow rate variables aside from share price. It was interesting that only the transaction volume increased for banks after they were included in the index. Borsa Istanbul Sustainability Index is considered a new index, and it is considered that the effect of banks on stock values and other performance indicators will turn positive as the index deepens. Keywords: Sustainability Index, Banks, Stock Market Performance, Statistical Analysis.

\section{INTRODUCTION}

In environmental science, sustainability can be explained as the ability of the elements of a system to continue its development and productivity in the future (Jeucken, 2010: 56). When the term "sustainability" is analyzed from an institutional viewpoint, it is stated that social, economic, and environmental factors are integrated after applying them to the decision mechanisms of businesses to make use of the organizations in the long term; however, they are performed in agreement with the corporate governance principles (Carnevale \& Mazzuca, 2014: 73). Also, corporate sustainability means the effective management of risks that may arise from such situations (Aras et al., 2010: 231).

In their study conducted on sustainability, Aliyu et al. (2017) argued that sustainability was the process of making some applications to meet the demands and needs of societies and to uncover their existing potentials in a sustainable period by providing continuous flexibility in ecological, sociological, and economic issues. In general, the concept of sustainability is an 
element determining the limits of the sustainability of an event or process with an unlimited time phenomenon.

As a result of the implementations of the stock markets in developed countries regarding the concept of sustainability in the global context, Borsa Istanbul laid the foundations for the establishment of the BIST Sustainability Index, which has been traded as of 2014, as an action towards the concept of sustainability, which is improving worldwide. In the abovementioned period, which corresponds to 2011, a questionnaire was conducted for 215 businesses in 11 different sectors trading in the stock exchange by PricewaterhouseCoopers-PwC, Turkish Business and Sustainable Development Association (SKD), and Istanbul Stock Exchange (ISE) at that time. As a result of the questionnaire, it was seen that $62 \%$ of the businesses adopt the sustainability policy and have an interest in sustainability (PwC, SKD, and ISE, 2011: 14).

The main target of the BIST Sustainability Index is to create an index to include businesses traded in Borsa Istanbul with high sustainability tendencies and to increase the knowledge, understanding, and operations regarding sustainability in Turkey and especially among BIST businesses. In this context, the practices aimed at adopting the BIST sustainability approach in organizations and on a social basis are gaining momentum.

The purpose of the study was to uncover significant differences for stock market performance indicators of Akbank, Garanti BBVA, Türkiye İş Bankası, Yapı Kredi Bank, Şekerbank, and TSKB, which are included in the Sustainability Index among the banks, which are the main elements of the finance sector, for 2013, when they were not included in the index, and for 2020 when they were included. In this way, it will be found out how being included in the Sustainability Index had effects on investors and whether it was reflected in the stock market performance indicators as a result. It is considered that the result to be obtained from this analysis will be a guide for investors and decision-makers. 


\section{CONCEPTUAL FRAMEWORK}

The corporate sustainability concept is an expression widely used in business literature and can be an option for continuous growth and profit maximization, which is accepted as one of the classical goals of organizations adding a modern understanding to organizational goals making a difference in business markets and allowing the traditional competition system to be interpreted from a different perspective (Aras et al., 2018: 602). The Sustainability Index is accepted as the reflection of corporate sustainability in financial markets (Carè, 2018: 95).

The sustainability concept can be explained as the resources used by humanity today, the evaluation of future generations by filtering moral, social, economic, legal, and legal values in a way to allow them to continue their vital actions at the most appropriate level (Raut et al., 2017: 554). The corporate sustainability expression can also be explained as "the effort of a business to maintain the profitability of assets as a living entity, perform activities to enable the protection and development of resources that can be used in the future while meeting current needs by turning to social and environmental activities as well as purely for economic profit to ensure the continuity of the enterprises” (Yip \& Bocken, 2018: 154). Corporate sustainability is based on the principles of agency theory, legitimacy theory, and stakeholder theory (Marti et al., 2015: 307).

Banks are institutions with social, economic, and environmental effects with funds provided, financing of investments, and other financial products and services. Based on this viewpoint, the analysis of sustainable banking practices, which is seen as a way of considering banks' financial products and services to support sustainable development, seems to be more important as time progresses (Özmen et al., 2020: 156).

However, it was also seen that social, economic, and environmental factors, which are considered as the main indicators of corporate sustainability, were no longer adequate alone for the sustainability studies of organizations. As well as the above-mentioned indicators, a quality 
management system and organizational management studies, and firm financial indicators are the components helping define the concept of corporate sustainability. For this reason, when the concept of sustainability is examined, a multi-faceted corporate sustainability system must be taken as the basis to include "finance" and "corporate management” elements along with social, economic, and environmental factors. It is also important to evaluate the sustainability activities in the banking sector, which has the effect of transforming all sectors with a powerful tool such as financing, in this multidimensional approach (Aras et al., 2020: 3).

The BIST Sustainability Index has been published since November 4, 2014, with the code “XUSRD”, in the form of returns and prices. The initial value of the index is 98.020.09, which was the closing of the Second Session of the BIST 30 price index on 03.11.2014. The weight of a share in the index is limited to 15\% (Borsa Istanbul, 2014a: 1).

There is 1 index period per year for the BIST Sustainability Index, from November to October. The businesses included in the BIST 30 Index in 2014 and businesses in the BIST 50 Index in 2015 were included in the evaluations. The list of businesses that were evaluated since 2016 was extended to include voluntary businesses of BIST 100 businesses as well as the businesses in the BIST 50 Index (Borsa Istanbul, 2014b: 3). The "List of Businesses Subject to Evaluation” is updated and announced by Borsa Istanbul in December of each year. When the index is calculated, the current prices recorded are used, and it is mainly calculated by using the coefficient market values of the shares in actual circulation in the index.

\section{LITERATURE}

In their study, Skare and Golja (2012) compared 45 businesses in the Sustainability Index in Dow Jones World with businesses that were not in the Sustainability Index in terms of sustainable performance and financials. As a result, they reported that businesses in the scope of the Sustainability Index performed higher than the businesses that were not in the scope of the Sustainability Index between 2006 and 2008.

\section{$\mathbf{R} \& S$}

Research Studies Anatolia Journal

Volume:5, Issue:1, January 2022 
Oberndorfer et al. (2013) compared the stock performance of German businesses in the Dow Jones Stoxx Sustainability Index and the Dow Jones World Sustainability Index in general. They used the data between 1999 and 2002 and found that German businesses were negatively affected by the sustainability index.

In the study that was conducted by Charlo, Moya, and Muñoz (2015), businesses in the Spanish Stock Exchange were compared by dividing them into 3 groups as those included in the Sustainability Index, those that were not included in it, and mixed. As a result of their study, it was found that the businesses in the Sustainability Index gained more at a similar risk level and adapted more quickly to the changes in the market.

Marti et al. (2015) compared the Stoxx Europe 600 Index and the Stoxx Europe Sustainability Indices. As a result, they reported that businesses in the scope of the Sustainability Index had higher financial performance in the 2007-2010 period.

In their study, Çitak and Ersoy (2016) compared the financial performances of businesses in the scope of BIST 30 and BIST Sustainability Index between November 2014 and June 2015. They used daily, weekly and monthly earnings rates of each business in the BIST 30 and BIST Sustainability Index, as well as the market capitalization/book value ratios as a case study, and average testing approaches were also used. According to the mean test result of the study, no statistical differences were detected between the mean earnings ratio of businesses in the Sustainability Index and the earnings ratios of BIST 30 businesses. It was also determined that the market value/book value ratio of the businesses in the index was higher than the market value/book value ratio of BIST 30 businesses. Considering the result of the case study, the average excess earnings ratio of the businesses in the index was not different from zero.

In the study that was conducted by Kestane (2016), the relations between the economic corporate sustainability, financial performance, and investor relations of businesses traded in the framework of the BIST Sustainability Index were evaluated for the dates of 2014-2015, and 
the data obtained from the financial statements were used using financial ratios (Profitability, Growth, Continuity and Stock Market Performance). A classification was made based on the pre- and post-index periods. It was determined in the study that there was a positive relationship between the financial performances and investor behaviors of the businesses in terms of economic, corporate sustainability practices in businesses outside the banking sector, but such a situation could not be detected in banks. It was also observed that being included in the Sustainability Index has a positive effect on the financial performance of both banks and nonbank businesses.

In their study, Santis, Albuquerque, and Lizarelli (2016) compared the financial performances of businesses included in the Brazilian Stock Exchange Sustainability Index and businesses that were not included in the index based on the 2010-2013 date range. As a result of their study, no significant differences were detected between the financial performances of the businesses in the index and the financial performances of the businesses that were not included in the index.

Altinay et al. (2017) examined the stock values of four banks in the BIST Sustainability Index for 2014 and 2017 before and after the index. As a result of their study, it was found that the stock values of the banks were higher before the index than the values after the index, but there was no statistical difference.

In the study that was conducted by Önder (2017), 91 businesses were selected from among the businesses in the scope of the BIST 100 Index, and the Multiple Linear Regression Analysis was used in the analyses by using the profit data for the pre-tax period in the annual reports of the businesses to measure the effects of their presence in the sustainability index on their profitability. In the analysis, it has been determined that being in the corporate sustainability index does not affect the profitability of the businesses. 
In the study conducted by Yıldırım, Kocamıs, and Tokur (2018), the purpose was to compare the financial performances of 9 businesses from among the businesses included in the BIST Sustainability Index for the five quarters before they were included in the index and the two quarters after they were included in it. The performance differences of the businesses were determined for the periods with the help of 10 financial ratios (Financial Leverage, Asset Turnover, Return on Equity, Return on Assets, Net Profit Margin, Current Ratio, Operating Profit Margin and Debt) and were measured using the $\boldsymbol{t}$-test statistical method. It was observed in the study that the financial performance increased positively after the inclusion of these businesses in the index, and there were significant differences in financial leverage, asset turnover, and return on equity performance indicators before and after the index.

In his study, Topal (2019) compared the financial performances of 11 businesses, and excluded banks that were continuously traded in the scope of the BIST Sustainability Index between 2014-2018, and 27 businesses excluding banks that were never included in the BIST Sustainability Index but were included in the BIST 100 list between the same dates. In this way, they aimed to compare the financial performances of businesses in the framework of sustainability actions with those that were not in the scope of sustainability actions. The panel data analysis was used in the comparison of the study covering 17 quarters by using ratio analysis. As a result of this analysis, it was found that the actions towards sustainability affect the return on assets of the businesses in a significant and positive way.

\section{METHOD}

\section{Type of Study}

The study had an applied descriptive study design. In this type of study, data are obtained with quantitative methods and statistical analysis of the obtained data is made. Since descriptive studies aim to define a certain phenomenon, they try to go into the details of the problem/case examined (Böke, 2009: 13). 


\section{The Study Problem}

The study problem was to uncover whether the stock market performances of the banks included in the Sustainability Index between the period when they were not included in the index and the period they were included. In most of the studies reported in the literature, it is suggested that the public perception and reputation of businesses that are included in the Sustainability Index changed positively, and therefore, their stock market performances also increased. In this study, this will be tested for banks included in the index in Turkey.

\section{The Hypotheses of the Study}

The main hypothesis of the study was that the stock market performance indicators differed at significant levels for 2013 when banks are not included in the sustainability index, and for 2020, when they are included. The hypotheses of the study are given in Table 1 .

Table 1. The Hypotheses of the Study

\begin{tabular}{|c|c|}
\hline & Hypotheses \\
\hline$\overline{\mathbf{H}_{1}}$ & Price/Earnings ratio shows a significant difference for the 2013 - 2020 period. \\
\hline $\mathbf{H}_{2}$ & $\begin{array}{l}\text { Market Value/Book Value ratio shows a significant difference for the } 2013 \text { - } 2020 \\
\text { period. }\end{array}$ \\
\hline $\mathbf{H}_{3}$ & Cash Flow ratio shows a significant difference for the 2013 - 2020 period. \\
\hline & $\begin{array}{l}\text { The Transaction Volume ratio shows a significant difference for the } 2013 \text { - } 2020 \\
\text { period. }\end{array}$ \\
\hline
\end{tabular}

\section{Population and Sampling of the Study}

The study population consisted of 8 banks in the BIST Sustainability Index as of 2020. Since

ING bank and Development Investment Bank data were not included in the Bloomberg Database, the sampling consisted of 6 banks. These banks were traded as Akbank, Garanti BBVA, Türkiye İş Bankası, Şekerbank, TSKB, and Yapı Kredi Bank. The data were obtained from the Bloomberg Database. The stock market performance ratios used in the study are given in Table 2. 
Table 2. Stock Market Performance Indicators Used in the Analysis

\begin{tabular}{ll}
\hline Stock Market Performance Indicators & Abbreviation \\
\hline Price/Earnings & P/E \\
\hline Market Value/Book Value & MV/BV \\
\hline Cash Flow Ratio & CFR \\
\hline Transaction Volume & TV \\
\hline Share Price & SP \\
\hline
\end{tabular}

\section{Analysis Method}

The Kolmogorov-Smirnov and Shapiro-Wilk Tests were used because the choice of method for the difference analysis to be used in the study was determined according to the normal distribution of the data. The $\mathrm{H}_{0}$ Hypothesis, which expresses the normal distribution, was taken since $\mathrm{p}>0.05$ for the data. In this case, the "Paired $\boldsymbol{t}$-test", also known as the conjugate $\boldsymbol{t}$-test, was applied for the period before and after the sustainability index.

\section{Findings and Discussion}

The Paired $\boldsymbol{t}$-test was used to test whether there were significant differences in stock market performances for the period 2013 when the bank group was not included in the BIST Sustainability Index and for the period 2020 when it was included.

Table 3. Paired $\boldsymbol{t}$-Test Results

\begin{tabular}{|c|c|c|c|c|c|}
\hline & & Mean & $\mathbf{n}$ & Std. Dev. & $\mathbf{p}$ \\
\hline \multirow{2}{*}{ Price/Earnings } & 2013 & 8.642 & 24 & 1.394 & \multirow{2}{*}{$0.000 *$} \\
\hline & 2020 & 6.585 & 24 & 3.847 & \\
\hline \multirow{2}{*}{ Market Value/Book Value } & 2013 & 1.272 & 24 & .256 & \multirow[b]{2}{*}{$0.000 *$} \\
\hline & 2020 & .570 & 24 & .171 & \\
\hline \multirow{2}{*}{ Cash Flow Ratio } & 2013 & 7.986 & 24 & 6.758 & \multirow{2}{*}{$0.000 *$} \\
\hline & 2020 & 3.427 & 24 & 4.011 & \\
\hline \multirow{2}{*}{ Transaction Volume } & 2013 & 1759121060.79 & 24 & 1292170927.24 & \multirow{2}{*}{$0.000^{*}$} \\
\hline & 2020 & 8733350180.20 & 24 & 7321777937.02 & \\
\hline \multirow{2}{*}{ Share Price } & 2013 & 4.329 & 24 & 2.873 & \multirow{2}{*}{0.152} \\
\hline & 2020 & 4.163 & 24 & 2.874 & \\
\hline
\end{tabular}

*Significant at 0.05

As a result of the analyses, it was found that other performance indicators, except for the share price, were different at significant levels. It was interesting was that only the trading 
volume increased after it was included in the index. The P/E, MV/BV, and CFR variables had higher values before the index.

According to these findings, Santis et al. (2016), Altinay et al. (2017) did not report any differences in performance rates in their study, and results that did not overlap with this study were reported. The studies of Charlo et al. (2015), Marti et al. (2015), Çıtak and Ersoy (2016), Kestane (2016) reported significant differences after adding to the index for some performance ratios. In this study, the only positive development was recorded for the transaction volume. Yildirim et al. (2018) and Topal (2019) studies stated that being included in the index showed a significant difference in performance rates, and was positive. In the present study, significant differences were obtained, but it was also found that there were more appropriate results in the period not included in the index.

The reason for these different results in the literature might be because of the selected variables, period evaluated, and the methods used. On the other hand, with the more positive pre-index values, it is considered that the sustainability index has only just begun to be recognized and the negative conditions seen in the world and our country during the period considered in the framework of the study had a negative effect on the index.

\section{CONCLUSION AND RECOMMENDATIONS}

In the present study, the effects of the Sustainability Index, which started to be calculated in Borsa Istanbul in 2014, on the stock market performance was examined for banks. In the scope of the study, statistically significant differences were detected between the mean values of the stock market performance variables before and after the Sustainability Index of 6 banks in the banking sector, whose data were obtained, for the Price/Earnings, Market Value/Book Value, and Cash Flow Ratio variables, except for the share price. The sustainability index is new. As the index deepens, it is considered that the effects of banks on stock values and other performance indicators will turn into positive attitudes towards the index.

\section{$\mathrm{R} \& S$}

Research Studies Anatolia Journal

Volume:5, Issue:1, January 2022 
Although Eccles et al. (2014) reported that the demands and expectations of investors on corporate sustainability increased and argued that institutional investors considered the ESG performance of businesses in their investment decisions, and the information sharing of enterprises on matters such as governance and sustainability was insufficient in terms of both quality and quantity.

The increased number of businesses included in the BIST Sustainability Index was considered important in terms of the studies to be conducted. It is considered that a more accurate result will be achieved with more samplings and diversified sectors. The fact that sustainability reports are accepted by more businesses as time progresses and they become a necessity as the demands of the businesses' stakeholders are shaped in the framework of sustainability shows the requirement to measure social and environmental performances as well as financial performances in the measurement of such studies. Considering the abovementioned situations in future studies will contribute to the literature. Since the index is new, when its changing and increasing content over time is evaluated, it is considered important to repeat similar studies over time and to examine whether different responses emerge. It is recommended to expand the comparative analyses with different variables and different methods for future studies.

Generally, corporate sustainability valuation and measurement must be emphasized and studied carefully in the world and Turkey. Especially in Turkey, businesses need to understand the necessity and importance of managing the social and environmental risks of the company well, along with financial performances in all business processes. In conclusion, the fact that they started to care more about sustainability studies also supports the acquisition of quality data in terms of academic studies. This will contribute to the realization of more comprehensive and qualified studies in this field in the future. However, the necessity of providing and processing qualified data on the measurement of sustainability performance, and the 
requirement for a qualified methodological method for the valuation and measurement to be conducted will make any original work on this subject become even more important.

\section{REFERENCES}

Aliyu, S., Hassan, M. K., Yusof, R. M. \& Naiimi, N. (2017). Islamic banking sustainability: a review of literature and directions for future study. Emerging Markets Finance and Trade, (53). 440-470.

Altınay, A., Kaki, B., Kestane, A., Soba, M., Dinçer, Ö. \& Şık, E. (2017). Sürdürülebilirlik endeksinin bankacilik sektörü hisse senedi değerlerine etkileri, BIST sürdürülebilirlik endeksi üzerine bir çalişma. Sosyal Ekonomik Araştırmalar Dergisi, 17(34). 264-284.

Aras, G., Aybars, A., \& Kutlu, O. (2010). Managing corporate performance: Investigating the relationship between corporate social responsibility and financial performance in emerging markets. International Journal of Productivity and Performance Management, 59(3). 229-254.

Aras, G., Tezcan, N. \& Furtuna, O. K. (2018). Multidimensional comprehensive corporate sustainability performance evaluation model: Evidence from an emerging market banking sector. Journal of Cleaner Production, 185(1). 600-609.

Aras, G., Tezcan, N., Kutlu Furtuna, Ö. \& Hacığlu Kazak, E. (2020). Sürdürülebilirlik değerlemesinde yeni yaklaşım: Çok boyutlu kurumsal sürdürülebilirlik modeli bankacilik sektörü değerlemesi, Y1ldız Teknik Üniversitesi Finans Kurumsal Yönetim ve Sürdürülebilirlik Merkezi (CFGS) Yayınları.

Borsa İstanbul. (2014a). Şirketler için sürdürülebilirlik rehberi. http://www.borsaistanbul.com/data/kilavuzlar/surdurulebilirlik-rehberi.pdf， （Erişim Tarihi: 11.09.2021). 
Borsa İstanbul. (2014b). Borsa İstanbul sürdürülebilirlik bülteni. http://www.borsaistanbul.com/docs/default-source/yayinlar/borsa-istanbul-2014surdurulebilirlik-bulteni.pdf?sfvrsn=4, (Erişim Tarihi: 11.09.2021).

Böke, K. (2009). Sosyal bilimlerde araştirma yöntemleri, Alfa Yayıncılık.

Carnevale, C. \& Mazzuca, M. (2014). Sustainability report and bank valuation: Evidence from european stock markets. Business Ethics, 23(1). 69-90.

Carè, R. (2018). Sustainability in banks: Emerging trends. In sustainable banking; Carè, R. (Ed.), Pallgrave Macmillan: Cham. 93-130.

Charlo, M. J., Moya, I. \& Munoz, A. (2015). M. Sustainable development and corporate financial performance: A study based on the FTSE4Good IBEX Index. Busines Strategy And The Environment, 24(4). 277-288.

Çıtak, L. \& Ersoy, E. (2016). Firmaların BIST sürdürülebilirlik endeksine alınmasına yatırımcı tepkisi: Olay çalışması ve ortalama testleri ile bir analiz, Uluslararası Alanya İşletme Fakültesi Dergisi, 8(1). 43-57.

Eccles, R., Ioannou, I. \& Serafeim, G. (2014). The impact of corporate sustainability on organizational processes and performance. Management Science, 60(11). 2835-2857.

Jeucken, M. (2010). Sustainable finance and banking: The financial sector and the future of the planet, Routledge Pbc.

Kestane, A. (2016). Kurumsal sürdürülebilirlik perspektifinde işletmelerin finansal performansinin analizi ve yatirimci davranişlari üzerine bir araştirma: BIST sürdürülebilirlik endeksinde bir uygulama, [Yayınlanmamış Yüksek Lisans Tezi, Dumlupınar Üniversitesi].

Marti, C. P., Rovira-Val, M. R. \& Drescher, L. G., (2015). Are Firms That Contribute to Sustainable Development Better Financially? Corporate Social Responsibility and Environmental Management, 22(5). 305-319. 
Oberndorfer, U., Schmidt, P., Wagner, M. \& Ziegler, A. (2013). Does the stock market value the inclusion in a sustainability stock index? An event study analysis for German firms. Journal of Environmental Economics and Management, 66(1). 497-509.

Önder, Ş. (2017). İşletme karlılığına kurumsal sürdürülebilirliğin etkisi: BİST’te bir uygulama. Muhasebe Bilim Dünyası Dergisi, 19(4). 937-956.

Özmen, A., Karakoç, M., Yeşildağ, E. (2020). Sürdürülebilirlik raporlaması: BIST sürdürülebilirlik endeksinde yer alan şirketler üzerine bir uygulama, Dumlupınar Üniversitesi Sosyal Bilimler Dergisi, 63(1). 153-174.

Raut, R., Cheikhrouhou, N. \& Kharat, M. (2017). Sustainability in the banking industry: A strategic multi-criterion analysis. Business Strategy and the Environment Journal, 26(4). 550-568.

Santis, P., Albuquerque A. \& Lizarelli, F. (2016). Do sustainable businesses have a better financial performance? A study on Brazilian public businesses . Journal of Cleaner Production, 133(2). 735-745.

Skare, M. \& Golja, T. (2012). Corporate social responsibility and corporate financial performance is there a link?, Economic Study, 25 (1). 215-242.

Topal, G. (2019). Sürdürülebilirlik çalışmalarının işletmelerin finansal performansına etkisi. [Yayınlanmamış Yüksek Lisans Tezi, İstanbul Aydın Üniversitesi].

Yıldırım, G., Kocamış, T. U. \& Tokur, Ö. T. (2018). Sürdürülebilirlik ve firma performansı: BİST sürdürülebilirlik endeksi şirketleri üzerine bir çalışma. Akademi Sosyal Bilimler Dergisi, 5(15). 90-96.

Yip, A. W. H. \& Bocken, N. M. P. (2018). Sustainable business model archetypes for the banking industry. Journal of Cleaner Production, 74. 150-69 